Marquette University

e-Publications@Marquette

$11-1-2011$

\title{
Folic Acid Supplementation Improves Vascular Function in Professional Dancers With Endothelial Dysfunction
}

\author{
Anne Z. Hoch \\ Medical College of Wisconsin \\ Paula Papanek \\ Marquette University, paula.papanek@marquette.edu \\ Aniko Szabo \\ Medical College of Wisconsin \\ Michael E. Widlansky \\ Medical College of Wisconsin \\ David D. Gutterman \\ Medical College of Wisconsin
}

Accepted version. PM \& R, Vol. 3, No. 11 (November 2011): 1005-1012. DOI. (C) 2011 Elsevier. Used with permission.

NOTICE: this is the author's version of a work that was accepted for publication in $P M \& R$. Changes resulting from the publishing process, such as peer review, editing, corrections, structural formatting, and other quality control mechanisms may not be reflected in this document. Changes may have been made to this work since it was submitted for publication. A definitive version was subsequently published in PM \& R, VOL 3, ISSUE 11, November 2011, DOI. 


\title{
Folic Acid Supplementation Improves Vascular Function in Professional Dancers with Endothelial Dysfunction
}

\author{
Anne Z. Hoch \\ Department of Orthopaedic Surgery/Cardiovascular Center \\ Medical College of Wisconsin \\ Milwaukee, WI \\ Paula Papanek \\ Department of Exercise Science, Marquette University \\ Milwaukee, WI \\ Aniko Szabo \\ Department of Population Health/Biostatistics \\ Medical College of Wisconsin \\ Milwaukee, WI \\ Michael E. Widlansky \\ Department of Cardiology, Medical College of Wisconsin \\ Milwaukee, WI \\ David D. Gutterman \\ Cardiovascular Center, Medical College of Wisconsin \\ Milwaukee, WI
}


NOT THE PUBLISHED VERSION; this is the author's final, peer-reviewed manuscript. The published version may be accessed by following the link in the citation at the bottom of the page.

\section{Abstract}

Objective. To determine if folic acid supplementation improves vascular function (brachial artery flow-mediated dilation [FMD]) in professional dancers with known endothelial dysfunction.

Design. Prospective cross-sectional study.

Setting. Academic institution in the Midwestern United States.

Subjects. Twenty-two professional ballet dancers volunteered for this study. Main Outcome Measures. Subjects completed a 3-day food record to determine caloric and micronutrient intake. Menstrual status was determined by interview and questionnaire. Endothelial function was determined as flowinduced vasodilation measured by high-frequency ultrasound of the brachial artery. A change in brachial diameter of $<5 \%$ to hyperemic flow stimulus was defined a priori as endothelial dysfunction. Subjects with abnormal FMD took $10 \mathrm{mg}$ of folic acid daily for 4 weeks, and FMD testing was then repeated. Serum whole blood was measured for folic acid levels before and after supplementation.

Results. Sixty-four percent of dancers $(n=14)$ had abnormal brachial artery FMD $(<5 \%)$ (mean \pm standard deviation, $2.9 \% \pm 1.5 \%)$. After 4 weeks of folic acid supplementation (10 $\mathrm{mg} /$ day), FMD improved in all the subjects $(7.1 \% \pm 2.3 \% ; P<.0001)$.

Conclusions. This study reveals that vascular endothelial function improves in dancers after supplementation with folic acid (10 mg/day) for at least 4 weeks. This finding may have clinically important implications for future cardiovascular disease risk prevention.

\section{Introduction}

Previous studies have shown that amenorrheic athletes have evidence of impaired vascular function manifested by reduced brachial artery flow-mediated dilation (FMD) to hyperemic stimuli $[\underline{1}, \underline{2}]$. Subjects in these studies consisted of college runners and endurance athletes in Sweden; none were dancers. Several studies have shown that ballet dancers have a high prevalence of amenorrhea [ $\underline{3}-\underline{5}$ ] and disordered eating [므- $\underline{8}]$. Therefore this group also may be at high risk for endothelial dysfunction.

Previous studies in athletes have shown a relationship between estrogen levels and brachial artery FMD [ㅇ] . It is known that coronary and peripheral vessels contain estrogen receptors, which allow estrogen to play a regulatory role in vascular function. Estrogen stimulates the production of nitric oxide (NO) through both genomic and non-genomic effects, leading to increased production of endothelial-derived NO, causing vasodilatation $[\underline{10}, \underline{11}]$. Estrogen exerts long-term genomic effects via alteration of gene and protein

PM \& R, Vol. 3, No. 11 (November 2011): pg. 1005-1012. DOI. This article is (C Elsevier and permission has been granted for this version to appear in e-Publications@Marquette. Elsevier does not grant permission for this article to be further copied/distributed or hosted elsewhere without the express permission from Elsevier. 
expression, mostly at the level of gene transcription, resulting in increased endothelial NO synthase (eNOS) synthesis and activity $[10,11]$. In addition to these genomic effects, evidence supports acute increases in eNOS via interaction with estrogen receptors on endothelial cells [12]. Finally, amenorrhea associated with athletes is known to have a steroid hormonal profile similar to that observed in menopause. Therefore low estrogen levels, whether in a postmenopausal woman or a young athlete with athletic-associated amenorrhea, will theoretically cause impaired endothelial cell function and resultant impaired arterial dilation $[\underline{1}, \underline{2}]$.

Abnormal endothelial dysfunction manifested as reduced brachial artery dilation has been shown to have a positive predictive value $(95 \%)$ for coronary endothelial dysfunction [13]. In addition, Schachinger and colleagues [14] have shown that coronary endothelial vasodilator dysfunction predicts long-term atherosclerotic disease progression and cardiovascular event rates. Woo and associates [15] have shown that brachial endothelial dysfunction correlates with the extent of coronary atherosclerosis. Therefore non-invasive assessment of brachial endothelial function by high-frequency ultrasound can provide valuable information about endothelial function in an otherwise healthy athletic population.. Early treatment in this group is important because cardiovascular disease is the number one cause of death in women in the United States.

Rickenlund and colleagues [16] have shown that administration of oral contraceptives (30 $\mathrm{\mu g}$ of ethinyl estradiol and $150 \mu \mathrm{g}$ of levonorgestrel) significantly improved brachial artery FMD in young amenorrheic runners. However, the Women's Health Initiative study showed an increased risk of breast cancer, heart disease, stroke, and blood clots among postmenopausal women who were using hormone replacement therapy that included both estrogen and progestin $[\underline{17}, \underline{18}]$. More recently, Chlebowski and colleagues [19] determined that synthetic hormone replacement therapy increases breast cancer risk and that these cancers tend to be more aggressive and lethal. Although these findings have not been found in premenopausal women, seeking an alternative treatment approach to reduced FMD in young athletes is reasonable.

PM \& R, Vol. 3, No. 11 (November 2011): pg. 1005-1012. DOI. This article is (C) Elsevier and permission has been granted for this version to appear in e-Publications@Marquette. Elsevier does not grant permission for this article to be further copied/distributed or hosted elsewhere without the express permission from Elsevier. 
Folic acid has potential benefits with regard to cardiovascular parameters such as endothelial function, arterial stiffness, blood pressure, and thrombotic activity [20-28]. Several studies have already shown that folic acid supplementation improves endothelial function in various disease states, including hypercholesterolemia

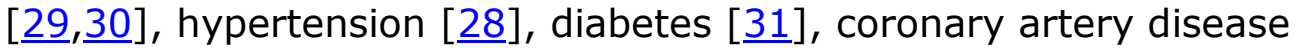
$[\underline{32}, \underline{33}]$, and hyperhomocystinemia [15]. These studies suggest that higher folic acid intake by specific populations may have vasculoprotective effects.

Several mechanisms explain the effectiveness of folic acid therapy. Folates are believed to participate in the endogenous regeneration of tetrahydrobiopterin [34], an essential cofactor for eNOS production of NO, and therefore may result in increased NO production after supplementation. Folic acid has a known homocysteine-lowering effect that could contribute to improvements in endothelial function. In addition, folic acid may have a direct antioxidant effect in the vasculature, increasing NO bioavailability, which is a major factor influencing the improvement in FMD $[13,32]$. Therefore the purpose of this study was to determine if folic acid supplementation of $10 \mathrm{mg}$ per day would increase FMD in professional dancers with reduced FMD.

\section{Methods}

\section{Subjects and Experimental Design}

This study was reviewed and approved by multi-institutional human subjects internal review boards. Inclusion criteria included professional female dancers, ages 18-35 years, from a single dance company in the Midwest. Exclusion criteria included a history of heart disease, vascular disease, hypertension, diabetes, hypercholesteremia, chromosomal disorder, current pregnancy, pituitary tumor, oral contraceptive use, anomalies of the reproductive system, and thyroid disease. Any subject taking a cardiac, cholesterol, hypertension, or thyroid medication was excluded from the study. Subjects were not excluded based on ethnicity. Twenty-two women met the criteria and completed the study. No women were excluded based on our criteria. The study was explained in person, and informed consent was

PM \& R, Vol. 3, No. 11 (November 2011): pg. 1005-1012. DOI. This article is @ Elsevier and permission has been granted for this version to appear in e-Publications@Marquette. Elsevier does not grant permission for this article to be further copied/distributed or hosted elsewhere without the express permission from Elsevier. 
obtained. Medical history and menstrual status were obtained through questionnaires and interview.

\section{Serum Folic Acid Levels}

Fasting whole serum folate levels were measured by the Bayer ADVIA Centaur assay (Siemens Medical Solutions Diagnostics, Deerfield, IL) before and after supplementation with folic acid. This assay is a competitive immunoassay that uses direct chemiluminescent technology. The inter-assay coefficient of variation was $5 \%-7 \%$, the intra-assay coefficient of variation was $4 \%-8 \%$, the lower limit of sensitivity was $0.35 \mathrm{ng} / \mathrm{mL}$, and the upper limit of sensitivity was $\geq 24$ $\mathrm{ng} / \mathrm{mL}$. Blood was drawn early in the morning after an overnight fast. Subjects with FMD $<5 \%$ were instructed to take folic acid ( $10 \mathrm{mg} /$ day) for 4 weeks. For standardization purposes, subjects were instructed to take their supplements in the morning with food. Subjects kept written logs and were randomly called to assess compliance.

\section{Dietary History}

Caloric micronutrient intake was determined from a prospective 3-day food diary recorded during 2 weekdays and 1 weekend day during the dance training season. A registered research dietitian met with each dancer for education and training in proportions or size of food servings, proper recording of foods, and the use of the food diary in general. Dietary analysis was performed by the research dietician with use of Nutrition Data System for Research software version 2007 (developed by the Nutrition Coordinating Center, University of Minnesota, Minneapolis, MN) to determine total calories; total composition of fat, protein, and carbohydrates; and micronutrient content (ie, folic acid, L-arginine, vitamin C, vitamin E, and vitamin B12). Subjects were encouraged to weigh their food portions for recording.

\section{Menstrual Status}

Self-administered questionnaires were used to determine menarche, number of periods per year, number of days between periods, skipped periods, history of thyroid disease or pituitary tumor,

PM \& R, Vol. 3, No. 11 (November 2011): pg. 1005-1012. DOI. This article is @ Elsevier and permission has been granted for this version to appear in e-Publications@Marquette. Elsevier does not grant permission for this article to be further copied/distributed or hosted elsewhere without the express permission from Elsevier. 
and use and type of birth control. A formal interview regarding menstrual status and medical history was conducted by the principal investigator. For the purpose of this study, eumenorrhea or regular cycling was defined as menstrual bleeding every 28-30 days. Primary amenorrhea was defined as absence of menarche by age 15 years and secondary amenorrhea was defined as cessation of menses for $>3$ consecutive cycles after onset of menarche, excluding pregnancy. Oligomenorrhea was represented by menstrual cycles with intervals greater than 35 days for at least 12 months. Luteal phase dysfunction was defined as a menstrual cycle less than 22 days. If subjects were taking oral contraceptives for treatment of secondary amenorrhea, they were identified as amenorrhea-oral contraceptive group. If they were taking oral contraceptives for any other reason, they were excluded from the study.

\section{Cardiovascular Status}

Brachial artery FMD and velocity were determined by techniques previously used in this laboratory $[\underline{1}, \underline{35}, \underline{36}]$. Subjects were studied in a supine resting position following an 8-hour fast in a temperaturecontrolled room. Systemic arterial pressure was periodically monitored in the nondominant arm with an automated sphygmomanometer. Subjects were instrumented for continuous recording of electrocardiogram, heart rate, and intermittent blood pressure. All subjects were tested at approximately the same time of day, with eumenorrheic, oligomenorrheic, and amenorrheic subjects studied in the early follicular phase of the menstrual cycle (day 4-8) [37-39]. Amenorrheic subjects were tested randomly as schedules permitted, but also in the early morning.

\section{Statistics}

Descriptive statistics are presented as mean \pm standard deviation (SD) for each measurement at baseline and after 4 weeks of folic acid supplementation. The primary outcome of interest for this study was change in brachial artery FMD before and after folic acid supplementation. A paired $t$-test was used to compare FMD before and after supplementation. All comparisons with the untreated group used an unpaired $t$-test, whereas all pre-post comparisons used a paired $t$ -

PM \& R, Vol. 3, No. 11 (November 2011): pg. 1005-1012. DOI. This article is (c) Elsevier and permission has been granted for this version to appear in e-Publications@Marquette. Elsevier does not grant permission for this article to be further copied/distributed or hosted elsewhere without the express permission from Elsevier. 
test. Based on Box-Cox analysis, all nutritional intake values were log transformed before the paired $t$-test. Because folic acid levels had an upper quantification threshold at $24 \mathrm{ng} / \mathrm{mL}$, a log-rank test was used when comparing the folic acid levels $(\mathrm{ng} / \mathrm{mL})$ of the abnormal FMD $(5 \%)$ group $(n=14)$ with the normal FMD $(>5 \%)$ group $(n=8)$ before supplementation with folic acid. The mean and SD of the underlying distribution were estimated by fitting a truncated normal distribution. The pre-treatment and post-treatment folic acids levels were compared using McNemar's exact test on the indicator of exceeding the $24 \mathrm{ng} / \mathrm{mL}$ threshold. All analyses were performed using $\mathrm{R}$ software version 2.10.1 [누].

\section{Results}

\section{Subject Characteristics}

Twenty-two elite dancers consented to participate and completed this study. Twenty dancers self-reported their ethnicity as Caucasian, one reported Asian ethnicity, and one reported Hispanic ethnicity, with an age of $23.2 \pm 4.7$ years (mean \pm SD). Table 1 provides descriptive demographics of the cohort including height, weight, percent body fat, body mass index, age, menarche, and years dancing divided into 2 groups based on whether FMD was abnormal $(<5 \%)$ or normal $(>5 \%)$. No difference in body mass index, percent body fat, or menarche was found between the 2 groups. A difference in age and years of dancing was found; the abnormal FMD group was younger and had danced fewer total years compared with the normal group.

PM \& R, Vol. 3, No. 11 (November 2011): pg. 1005-1012. DOI. This article is (C) Elsevier and permission has been granted for this version to appear in e-Publications@Marquette. Elsevier does not grant permission for this article to be further copied/distributed or hosted elsewhere without the express permission from Elsevier. 
Table 1. Descriptive demographics of cohort

\begin{tabular}{|c|c|c|c|}
\hline Characteristic & $\begin{array}{c}\text { Group With } \\
\text { Abnormal } \\
\text { FMD }(\mathrm{N}=14)\end{array}$ & $\begin{array}{c}\text { Group With } \\
\text { Normal FMD } \\
(\mathrm{N}=\mathbf{8})\end{array}$ & $P$ Value \\
\hline Age $(y)$ & $21.1 \pm 3.2$ & $27.0 \pm 4.3$ & .002 \\
\hline Height (in) & $64.8 \pm 2.1$ & $64.7 \pm 1.8$ & .94 \\
\hline Weight (Ib) & $115.6 \pm 11.2$ & $113.3 \pm 7.5$ & .62 \\
\hline Body fat (\%) & $17.6 \pm 5.2$ & $15.2 \pm 3.4$ & .28 \\
\hline $\begin{array}{l}\text { Body mass index } \\
\left(\mathrm{kg} / \mathrm{m}^{2}\right)\end{array}$ & $19.3 \pm 1.3$ & $19.0 \pm 0.7$ & .58 \\
\hline Menarche $(y)$ & $13.2 \pm 1.8$ & $14.1 \pm 1.5$ & .27 \\
\hline Dance history $(v)$ & $15.5 \pm 3.1$ & $19.5 \pm 5.0$ & .04 \\
\hline
\end{tabular}

FMD $=$ flow-mediated dilation.

Values are mean \pm standard deviation unless otherwise indicated.

$P$ value based on 2-sample t-test.

\section{Vascular Reactivity}

Brachial artery data are summarized in Table 2 and Figure 1. Table 2 includes data on heart rate (beats per minute), systolic arterial pressure $(\mathrm{mm} \mathrm{Hg})$, diastolic arterial pressure $(\mathrm{mm} \mathrm{Hg})$, temperature $\left({ }^{\circ} \mathrm{F}\right)$, relative humidity $(\%)$, baseline brachial artery diameter $(\mathrm{mm})$, FMD (\%), and peak change in flow velocity (\%). Abnormal FMD was defined by less than $5 \%$ dilation in response to an ischemic challenge $[35,36]$. This definition is based on data from our laboratory (normal $=$ $7.0 \% \pm 1.5 \%$; unpublished data) and others [41-43]. Subjects were subsequently divided into a normal group $(>5 \%, n=8)$ and a reduced group $(<5 \%, n=14)$. Brachial artery FMD was reduced in 14 of 22 dancers $(64 \%)$. Baseline brachial diameters, arterial pressures, resting heart rate, temperature, humidity, and peak change in flow velocity were not significantly different $(P>.05)$ between subjects with reduced and normal FMD (Table 2). After folic acid supplementation of $10 \mathrm{mg} /$ day for 4 weeks, all subjects had an increase in FMD (from $2.9 \% \pm 1.5 \%$ to $7.1 \% \pm 2.3 \%, P<.0001$ ) (Figure 1 ). Individual data for each subject before and after folic acid supplementation also is provided (Figure 2).

PM \& R, Vol. 3, No. 11 (November 2011): pg. 1005-1012. DOI. This article is (C Elsevier and permission has been granted for this version to appear in e-Publications@Marquette. Elsevier does not grant permission for this article to be further copied/distributed or hosted elsewhere without the express permission from Elsevier. 


\section{Brachial Artery Flow-Mediated Dilation Before \& After Supplementation}

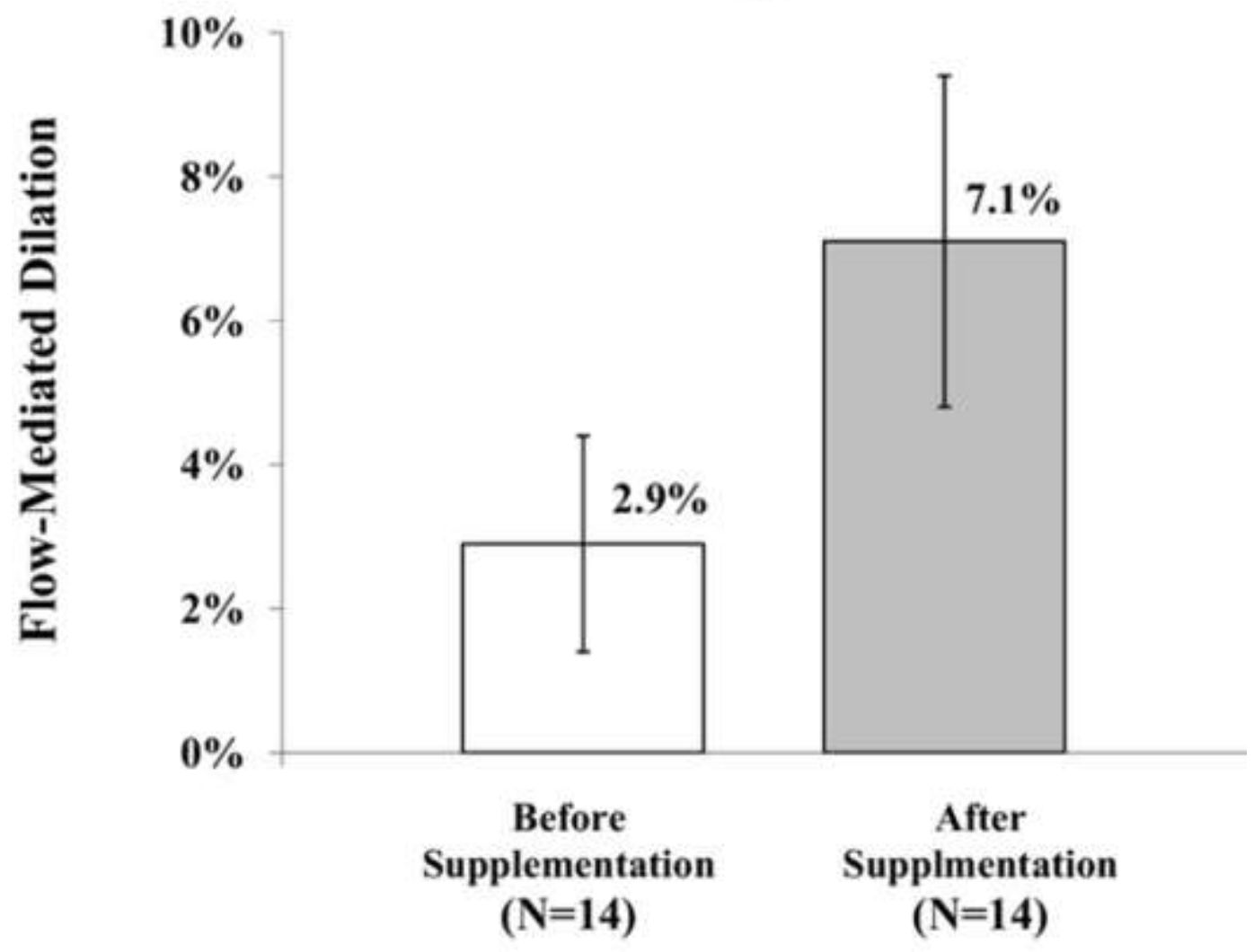

\footnotetext{
Abnormal defined a priori as $<\mathbf{5} \%$ $P$ values based on paired $t$ test Mean \pm SD shown
}

Figure 1. Fourteen dancers had reduced flow-mediated dilation (defined a priori as < $5 \%$ ). Flow-mediated dilation increased after folic acid supplementation.

PM \& R, Vol. 3, No. 11 (November 2011): pg. 1005-1012. DOI. This article is @ Elsevier and permission has been granted for this version to appear in e-Publications@Marquette. Elsevier does not grant permission for this article to be further copied/distributed or hosted elsewhere without the express permission from Elsevier. 


\section{Ballet Subjects with Abnormal FMD Values Before \& After Folic Acid Supplementation}

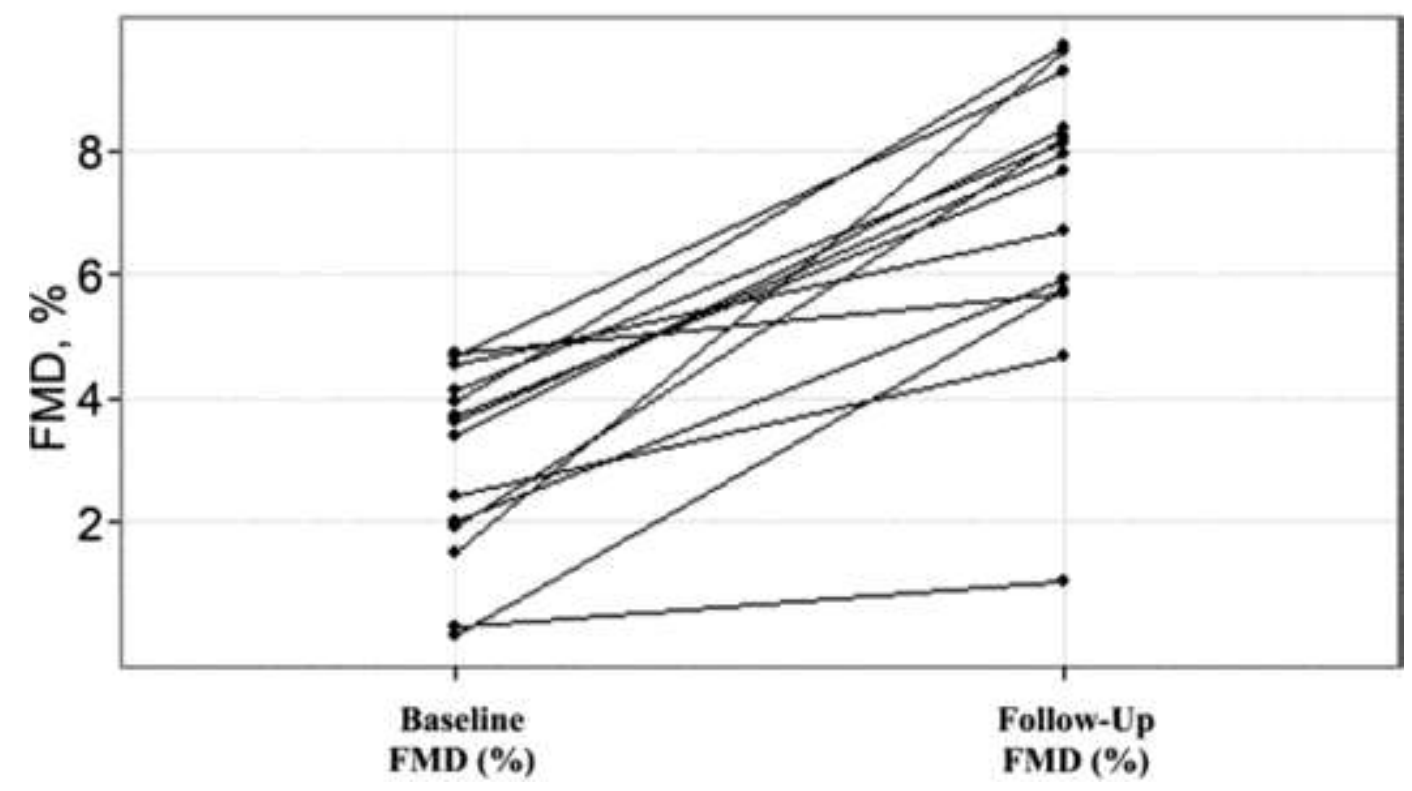

Figure 2. Individual data of the 14 dancers with reduced flow-mediated dilation before and after folic acid supplementation. FMD = flow-mediated dilation.

Table 2. Arochiof atery stucties betore and after fosc actd suppiementation (A priforl<58)

\begin{tabular}{|c|c|c|c|}
\hline Ballet Dancers $(N=14)$ & $\begin{array}{c}\text { Betore } \\
\text { supplementafion }\end{array}$ & $\begin{array}{c}\text { After } \\
\text { supplementation }\end{array}$ & P Value \\
\hline Heckt rafe (beats/mit) & $50.1 \pm 9.9$ & $58.4 \pm 14.9$ & .33 \\
\hline \multicolumn{4}{|l|}{ Mecri arterid pressure } \\
\hline Systolc (min $\mathrm{H}(0)$ & $1012 \pm 10.0$ & $102.1 \pm 9.6$ & 50 \\
\hline Dicstolic (crim $\mathrm{Ho})$ & $60.6=8.9$ & $03.7 \pm 8.2$ & 12. \\
\hline Temperature (क) & $69.3 \pm 1.3$ & $69.8 \pm 0.6$ & 09 \\
\hline Hemidity & $21.2 \pm 4.5$ & $21.3 \pm 4.7$ & 1.00 \\
\hline Bazeline bractial attary diameter (mm) & $28 \pm 0.3$ & $2.7 \pm 0.3$ & 35 \\
\hline Peak brachid atery dameter (mm) & $2.9 \pm 0.3$ & $29 \pm 0.4$ & 89 \\
\hline Fow-modatiend dibation (\$) & $2.9 \pm 1.5$ & $7.1 \pm 2.3$ & $<0001$ \\
\hline Peak changs in flow velccily (W) & $67.2 \pm 41.7$ & $69.1 \pm 25.5$ & 100 \\
\hline
\end{tabular}

Values are mean $=$ slandard deviation unless othenuise indicaled.

\section{Serum Folic Acid Levels}

No difference was found in serum folic acid between the abnormal FMD group ( $<5 \% ; \mathrm{n}=14 ; 19.2 \mathrm{ng} / \mathrm{mL} \pm 5.3$ ) and the normal FMD group ( $>5 \% ; \mathrm{n}=8 ; 17.3 \mathrm{ng} / \mathrm{mL} \pm 5.0$ ) prior to supplementation ( $P=.37$ ) (Figure 3 ). Folic acid levels increased in the folic acid treatment group after supplementation, but the exact amount is difficult to quantify because the highest value our laboratory reports is $24.0 \mathrm{ng} / \mathrm{mL}$; however, all post-treatment levels were above the cut-off value of $24 \mathrm{ng} / \mathrm{mL}$. In fact, the proportion of subjects above 
NOT THE PUBLISHED VERSION; this is the author's final, peer-reviewed manuscript. The published version may be accessed by following the link in the citation at the bottom of the page.

\section{$24 \mathrm{ng} / \mathrm{mL}$ increased significantly $(21 \%$ versus $100 \%, P=.001$ by exact McNemar's test) after supplementation (Figure 4).}

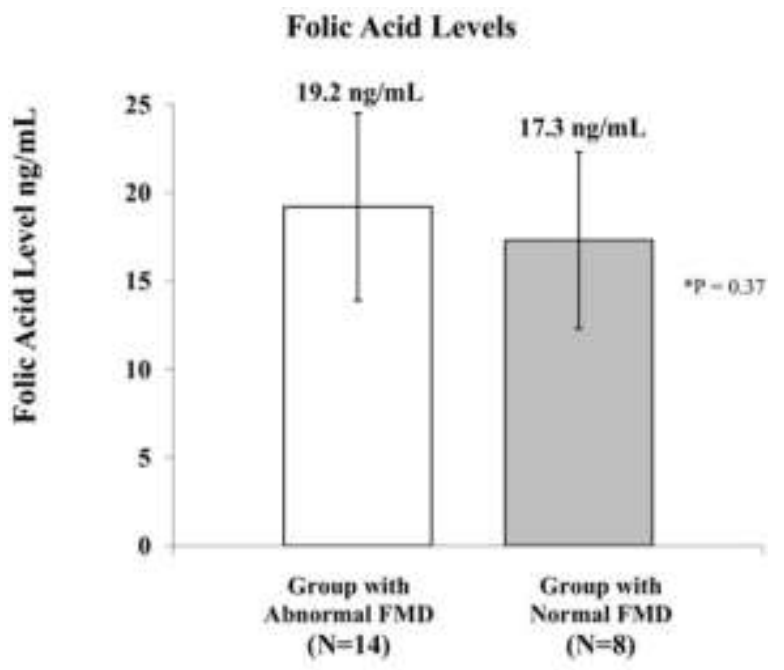

$P$ values based on log rank rest

Mean \pm SD shown

Figure 3. Folic acid levels before supplementation at start of study between group with normal flow-mediated dilation $(\mathrm{N}=8)$ and reduced flow-mediated dilation $(\mathrm{N}=$ 14). FMD = flow-mediated dilation. 


\section{Folic Acid Levels Before \& After Supplementation}

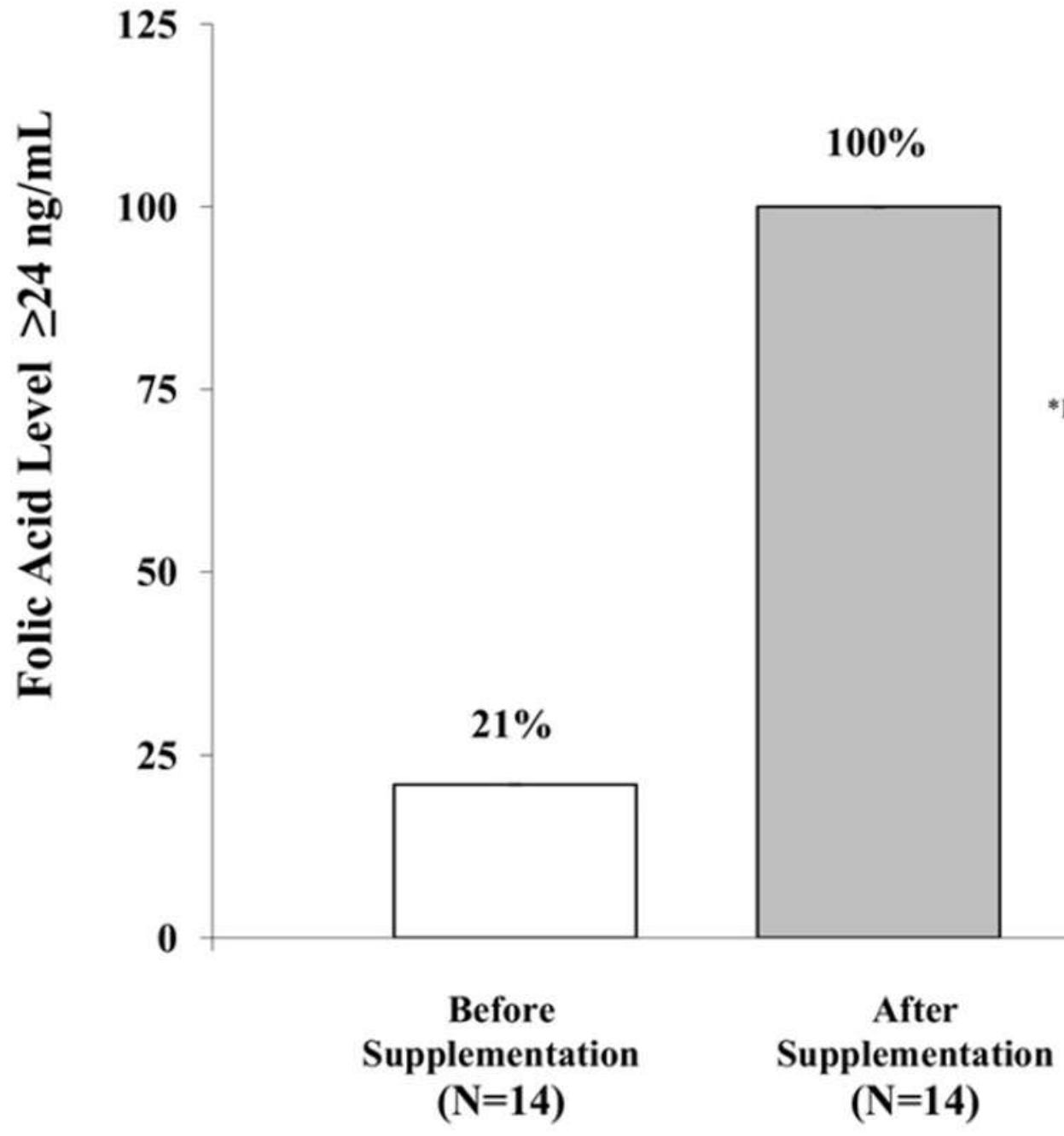

Abnormal defined a priori as $<\mathbf{5 \%}$

Normal after folic acid supplementation

$P$ values based on McNemar's exact test

Mean $\pm \mathrm{SE}$ is shown

Figure 4. Percentage of subjects who were above the laboratory threshold of 24 $\mathrm{ng} / \mathrm{mL}$ before and after folic acid supplementation ( $10 \mathrm{mg} /$ day for 4 weeks).

\section{Dietary Intake}

No difference was found in recorded dietary antioxidants (vitamin C and vitamin E), folic acid, or L-arginine (co-factor eNOS), 
all which can affect NO levels. In addition, no differences in vitamin D, vitamin B12, calories, protein, fat, or carbohydrates were found between the abnormal FMD group and normal FMD group $(P=.19)$ at the start of the study (Table 3 ).

Table 3. Nutritional data at start of study

\begin{tabular}{lccc}
\hline & $\begin{array}{c}\text { Group With } \\
\text { Abnormal } \\
\text { FMD (N = 14) }\end{array}$ & $\begin{array}{c}\text { Group With } \\
\text { Normal FMD } \\
(\mathbf{N}=\mathbf{8})\end{array}$ & P Value \\
\hline Vitamin D (IU) & $503.8 \pm 433.1$ & $433.8 \pm 303.8$ & .70 \\
Vitamin C (mg) & $601.6 \pm 1057.5$ & $729.1 \pm 421.6$ & .21 \\
Vitamin E (IU) & $239.7 \pm 482.1$ & $149.8 \pm 187.4$ & .88 \\
L-arginine (g) & $3.3 \pm 1.1$ & $4.1 \pm 1.4$ & .32 \\
Folic acid (mg) & $0.8 \pm 0.4$ & $0.7 \pm 0.4$ & .56 \\
Protein (g) & $62.0 \pm 23.2$ & $77.5 \pm 26.1$ & .19 \\
Fat (g) & $63.1 \pm 21.9$ & $73.5 \pm 29.5$ & .44 \\
Carbohydrates (g) & $259.2 \pm 85.3$ & $230.1 \pm 46.2$ & .37 \\
Energy (kcal) & $1809.6 \pm 572.3$ & $1883.8 \pm 479.2$ & .70 \\
Vitamin B12 $(\mu \mathrm{g})$ & $26.9 \pm 48.2$ & $23.9 \pm 11.8$ & .28 \\
\hline
\end{tabular}

Values are mean \pm standard deviation unless otherwise indicated.

\section{Amenorrhea/Oligomenorrhea}

At the time of the study, 2 dancers were amenorrheic (9\%) $(2.0$ \pm 0.1 years) and 6 dancers (27\%) were oligomenorrheic (menstrual cycles $>35$ days for at least 12 months). Collectively, $36 \%$ of 22 dancers self-reported current menstrual dysfunction, and they all had an FMD of less than 5\%. Three dancers (14\%) were taking contraceptive hormones because of a history of secondary amenorrhea. The relationship between FMD and menstrual status is reported in a previous study [ㅇ] .

\section{Discussion}

The main finding from this study is that $64 \%(n=14)$ of the dancers in a professional dance company had evidence of abnormal FMD and that FMD significantly improved with folic acid supplementation (10 mg/day) for 4 weeks. The baseline FMD of this group was $2.9 \%$, and it improved to $7.1 \%$ after supplementation.

PM \& R, Vol. 3, No. 11 (November 2011): pg. 1005-1012. DOI. This article is (C Elsevier and permission has been granted for this version to appear in e-Publications@Marquette. Elsevier does not grant permission for this article to be further copied/distributed or hosted elsewhere without the express permission from Elsevier. 
Several studies in older men and women with chronic diseases have shown an increase in FMD with folic acid supplementation $[\underline{30}, \underline{44}, \underline{45}]$. However, this is the first study to reveal that folic acid supplementation improves FMD in young professional dancers with endothelial dysfunction.

These findings are consistent with a previous study in young amenorrheic runners of similar age (mean $\pm S D$, age $22.1 \pm 4.8$ years) with a similar reduction in FMD, who showed similar improvement (3.0\% to $7.7 \%$ ) after folic acid supplementation (10 $\mathrm{mg} /$ day) for 4 weeks [35]. However, a significant methodological difference exists between these two studies. In the previous study of young amenorrheic women runners, altered menstrual status (ie, amenorrhea) was the primary inclusion criteria for the study group. In the present study of ballet dancers, the inclusion criteria for the experimental group were dancers with reduced FMD $(<5 \%)$ regardless of menstrual status.

In the present study of ballet dancers, all subjects with reported amenorrhea and oligomenorrhea had reduced FMD $(<5 \%)$. Two of the 3 subjects were taking synthetic hormones for amenorrhea, and 4 eumenorrheic subjects had reduced FMD ( $<5 \%)$. Although abnormal FMD in amenorrheic dancers is consistent with previous research $[\underline{1}, \underline{2}]$, the relationship between eumenorrhea and brachial artery FMD is not as clear. A 2009 study [36] evaluated eumenorrheic runners and brachial artery FMD. In this study, subjects were randomly assigned to placebo or folic acid (10 mg/day; 4 weeks) in a blinded fashion. Folic acid levels were measured before and after supplementation. Both groups had normal folic acid levels at the start of the study. After the supplementation period, the group taking folic acid had a significant increase in folic acid levels, whereas there was no change in folic acid levels in the placebo group. The group taking folic acid had a significant increase (3\%) in FMD compared with the placebo group $(0.11 \%)$, which had no increase. This finding is similar to that of the current study of ballerinas, which showed an increase in FMD in 4 eumenorrheic subjects with an initial FMD $<5 \%$. However, the data in eumenorrheic runners contradicts a 2010 study [35] which did not show an increase in FMD in eumenorrheic runners, only in amenorrheic runners, with folic acid supplementation. Possible explanations for the discrepancy in brachial artery FMD in eumenorrheic runners is most

PM \& R, Vol. 3, No. 11 (November 2011): pg. 1005-1012. DOI. This article is (C Elsevier and permission has been granted for this version to appear in e-Publications@Marquette. Elsevier does not grant permission for this article to be further copied/distributed or hosted elsewhere without the express permission from Elsevier. 
likely multifactorial. The laboratory for these studies only reported an upper threshold value of $24 \mathrm{ng} / \mathrm{mL}$ for serum folic acid levels. It may be that the eumenorrheic group in the 2010 study had a significantly lower folic acid level compared with the other studies. Aerobic fitness is also known to affect FMD values, and this variable was not measured in any of the studies. Finally, subjects may have incorrectly reported eumenorrhea, but they could truly have anovulatory cycles that could affect estrogen levels and FMD. Future studies with a larger cohort with more precise measurement of serum folic acid and estrogen levels are needed to further quantify the effect of folic acid in eumenorrheic athletes.

The risk of toxicity from folic acid intake from supplements and/or fortified foods is low [46]. Folic acid is a water-soluble vitamin that is regularly eliminated in the urine. No adverse effects of folic acid have been reported at $10 \mathrm{mg} /$ day $[\underline{15}, \underline{46}-\underline{49}]$, and the Food and Drug Administration MedWatch system does not list any adverse effects of folic acid that apply to this study [47]. Higher doses ( $>20 \mathrm{mg} /$ day) can cause adverse effects such as upset stomach, sleep disturbances, and skin problems. The recommended daily allowance for folate for women ages $19-50$ years is $400 \mu \mathrm{g} /$ day, and the tolerable upper intake level (UL) is $1 \mathrm{~g} /$ day. For women who have risk factors for neural tube defects, $4 \mathrm{mg}$ is recommended. It is important to recognize that the upper intake level refers to the amount of synthetic folate (folic acid) being consumed per day from fortified foods and/or supplements. There is no health risk and no UL for natural sources of folate found in food.

Despite the benefits of folic acid, some evidence indicates that high levels of folic acid can pose a variety of health risks. High doses of folic acid (>15 mg/day) can provoke seizures in patients taking anticonvulsant medications [49]. None of our subjects had a known seizure disorder. The National Institutes of Health [50] also states that caution regarding supplementation with folic acid should be used in patients with a vitamin B12 deficiency, because folic acid supplementation may hide the deficiency and silently exacerbate the condition. None of our subjects had low vitamin B12 levels as determined by their 3-day food record.

PM \& R, Vol. 3, No. 11 (November 2011): pg. 1005-1012. DOI. This article is (C) Elsevier and permission has been granted for this version to appear in e-Publications@Marquette. Elsevier does not grant permission for this article to be further copied/distributed or hosted elsewhere without the express permission from Elsevier. 
A recent study raises the possibility that folic acid supplementation might increase the risk of colorectal adenoma in patients with a known history of colorectal adenomas [51], but these data have not been confirmed in prospective trials. In this study [ $\underline{51}$, the rates of colon cancer recurrences were slightly higher at the first and second colonoscopic follow-up ( $44.1 \%$ and $41.9 \%$, respectively) when compared with the placebo control group $(42.4 \%$ and $37.2 \%$, respectively). This small observed increase may be related to more widespread screening and better detection. The evidence linking folic acid supplementation and an increase in colon cancer rates is inconclusive and merits further investigation. Folic acid has not been shown to directly cause colon cancer; however, if colon cancer is present, folic acid may fuel its growth [51]. The risks of folic acid supplementation are small and may be inconclusive with regard to increased colon cancer risk. In many patient populations, the benefits of folic acid supplementation likely outweigh the risks. From a clinical perspective, it would seem logical that if FMD was determined to be low, clinicians could potentially recommend folic acid on a daily basis to athletes; however, length of time and optimal dosage is still to be determined.

\section{Study Limitations}

These results must be interpreted in light of several limitations. The small sample size and cross-sectional design are methodologic shortcomings of this study. In addition, because of the inability of our laboratories to quantify serum folic acid above $24 \mathrm{ng} / \mathrm{mL}$, true folic acid levels were unknown. Finally, aerobic fitness was not determined, which is known to affect FMD. Future studies should include a larger cohort, with precise folic acid measurements in addition to metabolic testing.

\section{Conclusion}

In summary, this study showed that folic acid supplementation (10 mg/day for 4 weeks) significantly improved brachial artery FMD in professional dancers with reduced FMD. This finding may have clinical importance because reduced FMD is an accepted early sign of accelerated development of atherosclerosis, which may have an

PM \& R, Vol. 3, No. 11 (November 2011): pg. 1005-1012. DOI. This article is @ Elsevier and permission has been granted for this version to appear in e-Publications@Marquette. Elsevier does not grant permission for this article to be further copied/distributed or hosted elsewhere without the express permission from Elsevier. 
NOT THE PUBLISHED VERSION; this is the author's final, peer-reviewed manuscript. The published version may be accessed by following the link in the citation at the bottom of the page.

adverse health impact in this asymptomatic population of athletic professionals. Further studies should test this hypothesis in a larger cohort of dancers with and without endothelial dysfunction.

\section{Acknowledgment}

We thank Michael Pink and the Milwaukee Ballet Company for participating in this study.

This study was partially funded by Cullen Run/Walk Co-founder and Chair Gael Garbarino Cullen of Milwaukee, WI. It was also funded in part by the National Institutes of Health (5-M01-RR00058-39) and by the Clinical and Translational Science Award program of the National Center for Research Resources, National Institutes of Health (1UL1RR031973).

\section{Footnotes}

Peer reviewers and all others who control content have no relevant financial relationships to disclose.

\section{Contributor Information}

Anne Z. Hoch, Department of Orthopaedic Surgery/Cardiovascular Center, Medical College of Wisconsin, 9200 W Wisconsin Ave, Milwaukee, WI 53226.

Paula Papanek, Department of Exercise Science, Marquette University, Milwaukee, WI.

Aniko Szabo, Department of Population Health/Biostatistics, Medical College of Wisconsin, Milwaukee, WI.

Michael E. Widlansky, Department of Cardiology, Medical College of Wisconsin, Milwaukee, WI.

David D. Gutterman, Cardiovascular Center, Medical College of Wisconsin, Milwaukee, WI.

PM \& R, Vol. 3, No. 11 (November 2011): pg. 1005-1012. DOI. This article is @ Elsevier and permission has been granted for this version to appear in e-Publications@Marquette. Elsevier does not grant permission for this article to be further copied/distributed or hosted elsewhere without the express permission from Elsevier. 
NOT THE PUBLISHED VERSION; this is the author's final, peer-reviewed manuscript. The published version may be accessed by following the link in the citation at the bottom of the page.

\section{References}

1. Hoch AZ, Dempsey RL, Carrera GF, et al. Is there an association between athletic amenorrhea and endothelial cell dysfunction? Med Sci Sports Exerc. 2003;35:377-383.

2. Rickenlund A, Eriksson MJ, Schenck-Gustafsson K, Hirschberg AL. Amenorrhea in female athletes is associated with endothelial dysfunction and unfavorable lipid profile. J Clin Endocrinol Metab. 2005;90:1354-1359.

3. Warren MP, Brooks-Gunn J, Hamilton LH, Warren LF, Hamilton WG. Scoliosis and fractures in young ballet dancers. Relation to delayed menarche and secondary amenorrhea. N Engl J Med. 1986;314:13481353.

4. Warren MP, Brooks-Gunn J, Fox RP, Holderness CC, Hyle EP, Hamilton WG. Osteopenia in exercise-associated amenorrhea using ballet dancers as a model: A longitudinal study. J Clin Endocrinol Metab. 2002;87:31623168.

5. Brooks-Gunn J, Warren MP, Hamilton LH. The relation of eating problems and amenorrhea in ballet dancers. Med Sci Sports Exerc. 1987;19:4144.

6. Frusztajer NT, Dhuper S, Warren MP, Brooks-Gunn J, Fox RP. Nutrition and the incidence of stress fractures in ballet dancers. Am J Clin Nutr. $1990 ; 51: 779-783$.

7. Warren MP, Voussoughian F, Geer EB, Hyle EP, Adberg CL, Ramos RH. Functional hypothalamic amenorrhea: Hypoleptinemia and disordered eating. J Clin Endocrinol Metab. 1999;84:873-877.

8. Holderness CC, Brooks-Gunn J, Warren MP. Eating disorders and substance use: A dancing vs a nondancing population. Med Sci Sports Exerc. 1994;26:297-302.

9. Hoch AZ, Papanek P, Szabo A, Widlansky ME, Schimke JE, Gutterman DD. Association between the female triad athlete and endothelial dysfunction in dancers. Clin J Sports Med. 2011;21:119-125.

10. Mendelsohn ME. Protective effects of estrogen on the cardiovascular system. Am J Cardiol. 2002;89:12E-17E.

11. Chambliss KL, Shaul PW. Estrogen modulation of endothelial nitric oxide synthase. Endocr Rev. 2002;23:665-686.

12. Balligand JL, Feron O, Dessy C. eNOS activation by physical forces: From short-term regulation of contraction to chronic remodeling of cardiovascular tissues. Physiol Rev. 2009;89:481-534.

13. Anderson TJ, Uehata A, Gerhard MD, et al. Close relation of endothelial function in the human coronary and peripheral circulations. J Am Coll Cardiol. 1995;26:1235-1241.

$P M \& R$, Vol. 3, No. 11 (November 2011): pg. 1005-1012. DOI. This article is @ Elsevier and permission has been granted for this version to appear in e-Publications@Marquette. Elsevier does not grant permission for this article to be further copied/distributed or hosted elsewhere without the express permission from Elsevier. 
NOT THE PUBLISHED VERSION; this is the author's final, peer-reviewed manuscript. The published version may be accessed by following the link in the citation at the bottom of the page.

14. Schachinger V, Britten MB, Zeiher AM. Prognostic impact of coronary vasodilator dysfunction on adverse long-term outcome of coronary heart disease. Circulation. 2000;101:1899-1906.

15. Woo KS, Chook P, Lolin YI, Sanderson JE, Metreweli C, Celermajer DS. Folic acid improves arterial endothelial function in adults with hyperhomocystinemia. J Am Coll Cardiol. 1999;34:2002-2006.

16. Rickenlund A, Eriksson MJ, Schenck-Gustafsson K, Hirschberg AL. Oral contraceptives improve endothelial function in amenorrheic athletes. J Clin Endocrinol Metab. 2005;90:3162-3167.

17. Heiss G, Wallace R, Anderson GL, et al. Health risks and benefits 3 years after stopping randomized treatment with estrogen and progestin. JAMA. 2008;299:1036-1045.

18. Rossouw JE, Anderson GL, Prentice RL, et al. Risks and benefits of estrogen plus progestin in healthy postmenopausal women: Principal results From the Women's Health Initiative randomized controlled trial. JAMA. 2002;288:321-333.

19. Chlebowski RT, Anderson GL, Gass M, et al. Estrogen plus progestin and breast cancer incidence and mortality in postmenopausal women. JAMA. 2010;304:1684-1692.

20. Chambers JC, Ueland PM, Obeid OA, Wrigley J, Refsum H, Kooner JS. Improved vascular endothelial function after oral B vitamins: An effect mediated through reduced concentrations of free plasma homocysteine. Circulation. 2000;102:2479-2483.

21. Mangoni AA, Arya R, Ford E, et al. Effects of folic acid supplementation on inflammatory and thrombogenic markers in chronic smokers. A randomised controlled trial. Thromb Res. 2003;110:13-17.

22. Deol PS, Barnes TA, Dampier K, John PK, Oppenheimer C, Pavord SR. The effects of folic acid supplements on coagulation status in pregnancy. $\mathrm{Br}$ J Haematol. 2004;127:204-208.

23. Mangoni AA, Ouldred E, Swif CG, et al. Vascular and blood pressure effects of folic acid in older patients with cardiovascular disease. J Am Geriatr Soc. 2001;49:1003-1004.

24. Mangoni AA, Sherwood RA, Swift CG, Jackson SH. Folic acid enhances endothelial function and reduces blood pressure in smokers: A randomized controlled trial. J Intern Med. 2002;252:497-503.

25. Mangoni AA, Sherwood RA, Asonganyi B, Swift CG, Thomas S, Jackson $\mathrm{SH}$. Short-term oral folic acid supplementation enhances endothelial function in patients with type 2 diabetes. Am J Hypertens. 2005;18(2, pt 1):220-226.

26. Schutte $A E$, Huisman HW, Oosthuizen W, van Rooyen JM, Jerling JC. Cardiovascular effects of oral supplementation of vitamin C, E and folic acid in young healthy males. Int J Vitam Nutr Res. 2004;74:285-293.

PM \& R, Vol. 3, No. 11 (November 2011): pg. 1005-1012. DOI. This article is @ Elsevier and permission has been granted for this version to appear in e-Publications@Marquette. Elsevier does not grant permission for this article to be further copied/distributed or hosted elsewhere without the express permission from Elsevier. 
27. Undas A, Domagala TB, Jankowski M, Szczeklik A. Treatment of hyperhomocysteinemia with folic acid and vitamins B12 and B6 attenuates thrombin generation. Thromb Res. 1999;95:281-288.

28. van Dijk RA, Rauwerda JA, Steyn M, Twisk JW, Stehouwer CD. Long-term homocysteine-lowering treatment with folic acid plus pyridoxine is associated with decreased blood pressure but not with improved brachial artery endothelium-dependent vasodilation or carotid artery stiffness: A 2-year, randomized, placebo-controlled trial. Arterioscler Thromb Vasc Biol. 2001;21:2072-2079.

29. Verhaar MC, Wever RM, Kastelein JJ, van Dam T, Koomans HA, Rabelink TJ. 5-methyltetrahydrofolate, the active form of folic acid, restores endothelial function in familial hypercholesterolemia. Circulation. 1998; $97: 237-241$.

30. Verhaar MC, Wever RM, Kastelein JJ, et al. Effects of oral folic acid supplementation on endothelial function in familial hypercholesterolemia: A randomized placebo-controlled trial. Circulation. 1999;100:335-338.

31. van Etten RW, de Koning EJ, Verhaar MC, Gaillard CA, Rabelink TJ. Impaired NO-dependent vasodilation in patients with Type II (noninsulin-dependent) diabetes mellitus is restored by acute administration of folate. Diabetologia. 2002;45:1004-1010.

32. Doshi SN, McDowell IF, Moat SJ, et al. Folate improves endothelial function in coronary artery disease: An effect mediated by reduction of intracellular superoxide? Arterioscler Thromb Vasc Biol. 2001;21:1196-1202.

33. Doshi SN, McDowell IF, Moat SJ, et al. Folic acid improves endothelial function in coronary artery disease via mechanisms largely independent of homocysteine lowering. Circulation. 2002;105:22-26.

34. Wever RM, van Dam T, van Rijn HJ, de Groot F, Rabelink TJ.

Tetrahydrobiopterin regulates superoxide and nitric oxide generation by recombinant endothelial nitric oxide synthase. Biochem Biophys Res Commun. 1997;237:340-344.

35. Hoch AZ, Lynch SL, Jurva JW, Schimke JE, Gutterman DD. Folic acid supplementation improves vascular function in amenorrheic runners. Clin J Sport Med. 2010;20:205-210.

36. Hoch AZ, Pajewski NM, Hoffmann RG, Schimke JE, Gutterman DD. Possible relationship of folic acid supplementation and improved flowmediated dilation in premenopausal, eumenorrheic athletic women. J Sports Sci Med. 2009;8:123-129.

37. Hashimoto M, Akishita M, Eto M, et al. Modulation of endotheliumdependent flow-mediated dilatation of the brachial artery by sex and menstrual cycle. Circulation. 1995;92:3431-3435.

PM \& R, Vol. 3, No. 11 (November 2011): pg. 1005-1012. DOI. This article is @ Elsevier and permission has been granted for this version to appear in e-Publications@Marquette. Elsevier does not grant permission for this article to be further copied/distributed or hosted elsewhere without the express permission from Elsevier. 
38. Mather KJ, Norman EG, Prior JC, Elliott TG. Preserved forearm endothelial responses with acute exposure to progesterone: A randomized crossover trial of 17-beta estradiol, progesterone, and 17-beta estradiol with progesterone in healthy menopausal women. J Clin Endocrinol Metab. 2000;85:4644-4649.

39. Williams MR, Westerman RA, Kingwell BA, et al. Variations in endothelial function and arterial compliance during the menstrual cycle. J Clin Endocrinol Metab. 2001;86:5389-5395.

40. R Development Core Team. R: A language and environment for statistical computing. Vienna, Austria: R Foundation for Statistical Computing; 2006. [Accessed November 15, 2010]. Available at http://www.Rproject.org.

41. Brevetti G, Silvestro A, Schiano V, Chiariello M. Endothelial dysfunction and cardiovascular risk prediction in peripheral arterial disease: Additive value of flow-mediated dilation to ankle-brachial pressure index. Circulation. 2003;108:2093-2098.

42. Hijmering ML, Stroes ES, Pasterkamp G, Sierevogel M, Banga JD, Rabelink TJ. Variability of flow mediated dilation: Consequences for clinical application. Atherosclerosis. 2001;157:369-373.

43. Teragawa $H$, Kato M, Kurokawa J, Yamagata $T$, Matsuura $H$, Chayama K. Endothelial dysfunction is an independent factor responsible for vasospastic angina. Clin Sci (Lond) 2001;101:707-713.

44. Moens AL, Claeys MJ, Wuyts FL, et al. Effect of folic acid on endothelial function following acute myocardial infarction. Am J Cardiol. 2007;99:476-481.

45. Title LM, Ur E, Giddens K, McQueen MJ, Nassar BA. Folic acid improves endothelial dysfunction in type 2 diabetes - an effect independent of homocysteine-lowering. Vasc Med. 2006;11:101-109.

46. Hathcock JN. Vitamins and minerals: efficacy and safety. Am J Clin Nutr. 1997;66:427-437.

47. U.S. Food and Drug Administration. The FDA Safety Information and Adverse Event Reporting Program: Medical product safety information. [Accessed November 20, 2010]; Available at http://www.fda.gov/Safety/MedWatch/SafetyInformation/default.htm.

48. Birnbacher R, Messerschmidt AM, Pollak AP. Diagnosis and prevention of neural tube defects. Curr Opin Urol. 2002;12:461-464.

49. Herbert V. Folic acid. In: Shils M, Olson J, Shike M, Ross A, editors. Modern Nutrition in Health and Disease. Baltimore, MD: Williams \& Wilkins; 1999. pp. 433-466.

50. National Institutes of Health, Office of Dietary Supplements. [Accessed November 19, 2010];Dietary supplement fact sheet: Folate. Available at http://ods.od.nih.gov/factsheets/folate.

PM \& R, Vol. 3, No. 11 (November 2011): pg. 1005-1012. DOI. This article is @ Elsevier and permission has been granted for this version to appear in e-Publications@Marquette. Elsevier does not grant permission for this article to be further copied/distributed or hosted elsewhere without the express permission from Elsevier. 
NOT THE PUBLISHED VERSION; this is the author's final, peer-reviewed manuscript. The published version may be accessed by following the link in the citation at the bottom of the page.

51. Cole BF, Baron JA, Sandler RS, et al. Folic acid for the prevention of colorectal adenomas: A randomized clinical trial. JAMA.

2007;297:2351-2359.

PM \& R, Vol. 3, No. 11 (November 2011): pg. 1005-1012. DOI. This article is @ Elsevier and permission has been granted for this version to appear in e-Publications@Marquette. Elsevier does not grant permission for this article to be further copied/distributed or hosted elsewhere without the express permission from Elsevier. 